\title{
Correction: Understanding the needs of professionals who provide psychosocial care for children and adults with disorders of sex development
}

Dessens A, Guaragna-Filho G, Kyriakou A, et al. Understanding the needs of professionals who provide psychosocial care for children and adults with disorders of sex development BMJ Paediatrics Open 2017;1:e000132. doi: 10.1136/bmjpo-2017-000132.

The funding information for this paper was missed off by the production team, we would like to apologise for this oversight. This survey was conducted as part of the COST Action BM 1303 DSDnet, supported by COST (European Cooperation in Science and Technology, www.cost.eu/COST_Actions/bmbs/BM1303). The International Disorder of Sex Development (I-DSD) Registry is supported by Medical Research Council partnership award G1100236 (Ahmed, Bryce, Jiang, Lucas-Herald, Rodie and Sinnott) and was initially developed under a project grant from the Seventh European Union Framework Program (201444) and a project grant from the Research Unit of the European Society for Paediatric Endocrinology. Guaragna-Filho was supported by CAPES Foundation, Ministry of Education of Brazil (BEX 3547-15-9).

Open Access This is an Open Access article distributed in accordance with the Creative Commons Attribution Non Commercial (CC BY-NC 4.0) license, which permits others to distribute, remix, adapt, build upon this work non-commercially, and license their derivative works on different terms, provided the original work is properly cited and the use is non-commercial. See: http://creativecommons.org/licenses/by-nc/4.0/

C Article author(s) (or their employer(s) unless otherwise stated in the text of the article) 2018. All rights reserved. No commercial use is permitted unless otherwise expressly granted.

BMJ Paediatrics Open 2018;2:e000132corr1. doi:10.1136/bmjpo-2017-000132corr1

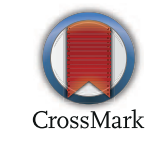

